\title{
Postcolonial leadership between the sovereign and the beast
}

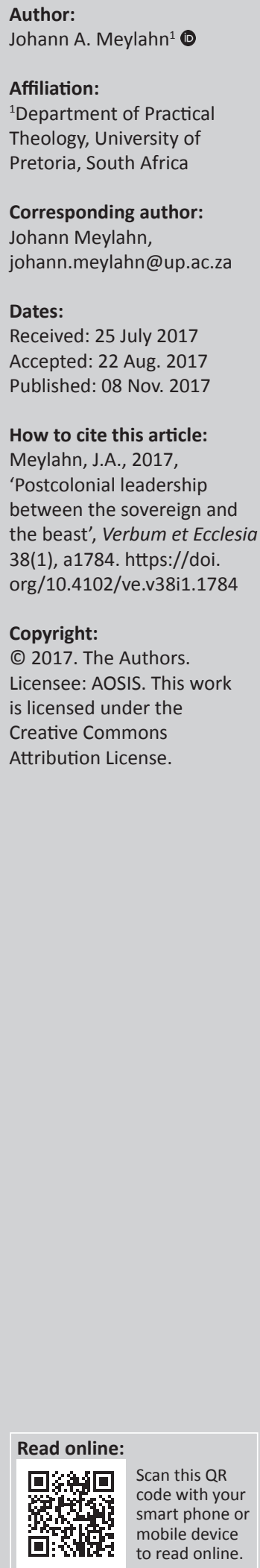

There is a crisis in leadership throughout the world, but the focus of this article will be on the crisis in postcolonial Africa. How is this crisis constructed within the politics of the global village? The leadership crisis in Africa is often portrayed by Western-influenced media as leaders being beasts if they do not comply with the wishes and dictates of Western capital, or characterised as puppets of Western capital, a puppet of the Western sovereign. Is there a way beyond these characterisations, or is it a political necessity to divide the world into friends and enemies, as Carl Schmitt would like us to believe? Taking Derrida into consideration, a way will be sought beyond this characterisation. Derrida's ideas concerning the sovereign will pose the question: can leadership move beyond being either a puppet of a Western sovereign or being the beast of darkest Africa? The article will argue that the political gathering into a collective will not be destroyed if this distinction disappears, although the distinction will be ruined. Yet, these ruins will be the place for the possibility of something other, an impossible possibility - the madness of the impossible possible, or the madness of holy folly and the hope and dream of leadership still to come.

Intradisciplinary and/or interdisciplinary implications: The article addresses the postcolonial context, specifically of Africa, but not limited to Africa. It challenges traditional theories on leadership and proposes a hermeneutical approach to interpreting and understanding leadership.

\section{Introduction}

The purpose of this article is to read various theories and ideas on leadership within their worldsof-construction and thereby deconstruct the various ideas or theories on leadership whilst opening these ideas to a leadership that is still to come. This article is written from a South African perspective with the general opinion that there is a leadership crisis in Africa. I will use this apparent crisis in leadership in Africa to illustrate a deconstructive reading of leadership theories by placing the various theories into their respective narrative contexts, using two dominant discourses concerning leadership in Africa as the material for this article, without personally taking sides in these two opposing views.

\section{Leadership crisis in Africa: Two dominant narratives}

There is a crisis in leadership in Africa and this raises the question, can Africa be saved? This question can only be answered if one knows what Africa has to be saved from. According to the dominant media, specifically after the latest (2015) immigration or refugee tragedies in the Mediterranean ocean, Africa needs to be saved from wars, corrupt leaders and extreme poverty. Africa needs to be saved from being hopeless Africa as the The Economist (2000) describes Africa or the lost continent as The Socialist Party of Great Britain (2000) describes Africa. There are so many crises facing Africa, and the general opinion is that the cause and the solution of these crises are to be found in leadership (Matsengarwodzi 2013).

The cause for the crises is bad, incompetent and corrupt leadership. The corrupt leaders are driven by:

self enrichment, thereby abusing their subjects' trust. Their goals are limited: If they are not war mongers, they are consolidating absolute power oblivious of the route they take. In the process they utilise force that their atomic minds can assume to turn their agendas into immortal theories ignoring glaring resistance. (Matsengarwodzi 2013:n.p.)

This leadership crisis is playing well into the hands of Western capital, as it allows the West to keep their hands deeply buried in the mineral and natural wealth of Africa (Worldsocialism 
2000). ${ }^{1}$ Therefore, the West is often interpreted as being part of the problem, as certain Western States support corrupt leaders, ${ }^{2}$ helping them and keeping them in power so as to insure their (Western) influence and thereby protect their economic interests. The West's help in solving the leadership crises is often in the form of funding and developing leadership academies. The leadership theories and management theories developed and proclaimed by these leadership academies are all designed and developed in the West and thus are part and parcel of the Western world. ${ }^{3}$ Keeping in mind that most leadership and management theories are designed not to transfer skills to Africa, but to help 'western managers to do business in Africa' (Bolden \& Kirk 2009:73). A good example that illustrates this point is how the Aspen Academy (Aspen n.d.) interprets the problem of the leadership crisis in Africa and offering a typical 'Western' solution. The general argument is that there is a crisis of leadership in Africa. The result is continued poverty for millions of men, women and children. The causes of this crisis are numerous. But high among them is the fact that many African countries lack a broadly shared vision of the future that effectively melds the demands of globalisation with local values. For there to be progress, the next generation of leaders in all three sectors must come together:

- to identify and address their personal strengths and weaknesses as leaders

- to understand the challenges they face as participants in a rapidly globalising society

- to share and refine their respective visions of the society they would like to live in

- to lead by example in building this society.

The dominant interpretation of the leadership crisis in Africa is that Africa and African leaders are backward and that Africa does not really have what it takes to become a 'civilised' continent, and therefore needs Western aid in the form of leadership theories and management skills. This attitude can very easily lead to what has been called Afropessimism, as no solutions to the problems are foreseen, and Africa is presented as a failure (Ayittey 1998; The Economist 2000). It is a failure because Africa is portrayed as corrupt, hopeless, criminal and ungovernable (Andreasson 2005; DeMaria 2008; Harris, Moran \& Moran 2004; Martin 2008).

1.'The food giants, Nestlé and Cadbury buy only cocoa beans from Africa, at prices fixed by them. Cocoa beans from Ghana, Cote d'Ivoire, Nigeria, Cameroon and Sao Tome \& Principe come to steal processing plants in Europe thereby denying these countries the profits they would have otherwise accrued from exporting finished cocoa products. Ghana has been cultivating cocoa for over a century now, yet we can only boost of one cocoa processing plant at Tema. African leaders have every right to blame colonialism for the continent's problems' (Bob-Milliar 2005:n.p.; see also Coote 1995:75-104)

2.'Most of the African dictators ... were and are in power because of the support they enjoy from western governments' (Bob-Milliar 2005). 'Africa has been deprived of some of its most charismatic, able and independent minded leaders (Dr. Kwame Nkrumah, Patrice Lumumba etcetera) by the direct involvement of Western governments in African affairs' (Bob-Milliar 2005:n.p.).

3.'Leadership theory emanates primarily from the United States based on studies of American leaders. Yet, leadership theory is largely represented as universal and scholars often do not notice the "universal" is indeed specific' (Nkomo 2011:371). scholars often do not notice the "universal" is indeed specific' (Nkomo 2011:371) 'Corporate culture as experienced in South Africa is very Eurocentric. Business practice as currently conceptualised in most South African corporations is generally cast in a Eurocentric mould, in fact, worse, an Anglo-Saxon mould' (Khoza 1994:121). Therefore, because it is created in a different world, it cannot be imposed on another culture that is seen to be essentially different to the world in which the theory originated (Khoza 1994:121).
If Africa is a failure, what test has it failed? Who set the test, and who set the standard and the norms? To counter, or in response to this Afro-pessimist view, there are those who argue that this is not necessarily a true reflection, but only how the West portrays Africa, and then they offer an 'explanation' for this 'failure', but thereby agreeing that it is a failure (Bob-Milliar 2005).

For example, in response to Afro-pessimism, there is the New Partnership for Africa's Development initiated by the African Union, which calls for an African Renaissance - a renaissance where Africa solves its own problems and looks for answers not in Western theories and ideas, but from within the African culture or world view. The slogan, Africa will solve Africa's problems in an African way, tries to counter the Western Afropessimist view.

How will Africa solve Africa's problems in an African way? Is there an African way and is there a Western way? The idea of an African way is based on the conviction that there is an African way that is fundamentally and essentially different from the Western way. To be able to find and develop this African way, the mind or soul of Africa must be liberated from the shackles of imperialist or colonialist Western epistemologies and world views, and then seek Africa's own unique voice and contribution. These ideas link up well with most postcolonial (Bhabha 1994; Said 1979, 1993; Spivak 1988) and/or anti-colonial (Césaire 1972; Fanon 1967, 1990; Senghor 1964, 1994) or nationalist (Appiah 1992; Mbembe 1992, 2001, 2002a, 2002b; Mudimbe 1988) approaches. The problem with these movements is their essentialist understanding of race or culture and/or a glorification of Africa's undocumented past. The idea that Africa has something unique to offer the world is found in various forms of African nationalism, such as Négritude, Pan Africanism, African Socialism and African Humanism (Nkomo 2011:368) and, one could add, Ubuntu (see Meylahn 2017).

Such nationalist theories lead to a clash of essentialisms, as the West is portrayed as being essentially this or that, and Africa is portrayed as being essentially something different to the West. The West is generally portrayed as having all characteristics which Africa either lacks or essentially does not subscribe to. African nationalism agrees that Africa lacks that which makes the West 'successful', but that which the West sees as a lack or as a stumbling block to successful leadership and management in Africa is interpreted as something positive and unique to Africa, and could offer a cure for some of the challenges that the 'successful West' faces. For example, the idea of Ubuntu as something that Africa can offer the world to make the world more humane, and transform the individualistic West into something more communitarian.

The negative essential characteristics of Africa which were interpreted as the cause of management and leadership failures - for example sensuality, rhythm, earthiness, mysticism and communalism - are therefore transformed into 
positive markers for humanity. Another example of such a reinterpretation of African essentialism is Senghor's negritude (Nkomo 2011:368). The main criticism of African nationalism and anti-colonialism is that it transforms race and/or culture into something essential and static, which is somehow inherent to a particular race. Part of this cultural or racial thinking is a call for a return to a time before this particular race or cultural group was influenced by the other races, that is, to pre-colonial Africa, where apparently there were no problems and the whole of Africa lived in peace and prosperous harmony. Obiakor argues, for example, that there was pre-colonial African capitalism that worked (Obiakor 2004:406). This pre-colonial time also saw strong patriotic leaders, who were developed from within the community and for the community (Obiakor 2004:407). These ideas argue that there was a time when Africa did not fail the test set by Western standards, but these theories still accept the test as universal and valid.

In the above paragraphs, I have tried to sketch two dominant narratives in which leadership and the leadership crisis in Africa are embedded. It is the struggle between these two narratives, maybe best characterised by President Robert Mugabe often portrayed in Western media as an ape in cartoons, whilst his counterpart Morgan Tsvangirai is often portrayed as a puppet of Western capital (the Herald 2013) in Zimbabewean nationalist media. In this article, I will not argue my personal opinion on these leadership 'styles', nor will I argue for one or the other of the current dominant interpretations, that African leaders are either corrupt and incompetent or puppets of Western capital, but place these characterisations into their particular narrative contexts.

These narratives are dominant and influence many of the comments made about African leaders as either being backward, wayward or primitive on the one hand, or as puppets of the West. For example, a recent quote from the media on president Zuma:

The vice-chancellor of the University of the Witwatersrand, Adam Habib, recently argued that: 'Zuma's idea of leadership is that of a "chieftaincy" in which he provides from the government largesse and expects something in return'. Meaning, we are stuck with selfish leaders who are ready to stick to their wayward behaviours despite their glaring failures. (Matsengarwodzi 2013:n.p., author's own emphasis)

Interpretations and/or critique of leadership are always emplotted within a narrative. In other words, the styles or characteristics of leaders are emplotted, to use a term from Ricoeur (1984:169), into a narrative and in and through that narrative the ideas concerning leadership make sense and have meaning. Each of these above-mentioned leadership challenges are placed into different narratives. There are the generally accepted dominant interpretations of what is happening in Africa, which, in turn, depends on the context of interpretation. One such dominant interpretation, or emplotment, is the Western criticism of these backward leadership styles (Afro-pessimism) and the other is the African nationalist response, arguing that they will refuse to submit to the neocolonialism of Western morals or ethics and world view, and rather seek an African solution to African problems. There are numerous other narratives; for example, those that seek to explain these events or practices within the light of the global-political or geo-political narrative, namely that both these characterisations are just part of a game plan of global capital to insure access to important natural and mineral resources.

\section{Leadership}

What is leadership? Well, it is many different things, depending on the narrative that it is part of, or the context in which it is spoken of. For example, at a conference on leadership, leadership could be seen as a hot topic and if you add Africa to the topic it becomes an even hotter topic. If 'African leadership' is in the title of a research project, it will probably guarantee good funding, which is becoming very scarce in faculties of the humanities. There is a proviso, though: that your interpretation of leadership coincides with the ideas of leadership as formulated by the leading leadership experts of the West, such as Leadership Magazine (n.d), Forbes.com's interpretation of leadership (Forbes, n.d.), the Aspen institute's (Aspen institute, n.d.) understanding of good leadership or the African Leadership Academy's (African leadership academy, n.d.) ideas, because all these ideas are believed to save Africa from itself.

A different narrative is that one is truly interested in leadership, and one has a concern (Sorge) for this beloved continent and her people. This article is about deconstructing the narratives of leadership by reading the various concepts of leadership within their world-constructions. This deconstruction is dependent on the thoughts of both Heidegger and Derrida and therefore the use of various German terms linking these thoughts to those of Heidegger.

There are different narratives in which leadership is my Sorge - the academic world with its funding opportunities and the life world of this continent and my existential being-there (Dasein) in this context. In all these worlds, leadership plays a role and therefore my concern (Sorge) with the topic. This Sorge for this continent again is not neutral or objective, but one's Dasein in this Mitsein is part of a particular Austrag of a particular world.

The method in this article is to read the various theories on leadership in Africa in their specific narrative contexts, whilst seeking that which is forgotten or not said, and thereby witness a certain auto-deconstruction of these various leadership theories or ideas. The intention of such a reading is not to arrive at the understanding of leadership, or to develop the leadership theory, but to maybe create a certain democracy-of-thought (Laruelle 2013a:kindle 187) concerning leadership in Africa. My suspicion is that there is no democracy-of-thought, not just the obvious domination of the thought on leadership by two differing paradigms, but that there are numerous voices that are unheard, and perhaps space can be created to hear these voices. Not because these 
voices have the truth on leadership, but because these voices might challenge the dominance of certain voices and thereby create a sense of justice by giving other voices a platform to be heard. Such a democracy-of-thought could possibly open a more inclusive space, allowing ever more voices to be heard and specifically also the voices of the vulnerable and marginalised.

\section{The narratives of leadership theories or the differing worlds of leadership theories}

Every theory on leadership is emplotted within a specific narrative and these narratives carry out $\left(\mathrm{Austrag}^{4}\right)$ a particular world. Or one could say, carry out various differing worlds, as there is a world believed to be behind the text, a world implied in the text, and a world created in front of the texts on leadership. There are no universal ideas or theories on leadership, as each theory is embedded in a particular narrative and through the narrative (language) leadership is disclosingly appropriated (see Heidegger 1971:202-203; Hofstadter 1971:xxi) into a particular world. The author of a particular leadership theory, with his or her text, wishes to convince the reader that these differing worlds all refer to the same world; the same world we all share, and because we all share the same world, it is believed possible to formulate a universal theory on leadership. The two dominant ideas that have been mentioned above are both emplotted into narratives that carry out (Austrag) a particular world, either the world of Western management and leadership or the world of African nationalism. In these two differing worlds, leadership is either seen within the Western world, which is stereotypically interpreted as being individualistic, goal driven and so on, whilst African leadership is stereotypically presented as being human-orientated, consensus-driven and so on. In one sense, these differing views are good as the difference breaks the hegemony of the single universal idea of leadership. Numerous studies have been conducted taking these cultural differences into considerations. One of the main theorists concerning cultural differences in leadership studies is Geert Hofstede (1980, 1993). Other studies that have focussed on cultural differences are House (1993, 1996), House, Wright and Aditya (1997), House et al. (1998) and Triandis (1995). There is also a South African study (Booysen 2001) that focusses on cultural difference in leadership, namely the differences between black and white leadership styles.

What is forgotten (Seinsvergessenheit) is that each of these theories on leadership is emplotted within a particular narrative that, in turn, is embedded within a particular world or culture. I do not want to argue for cultural essentialism, where distinct essential characteristics are identified with different race groups as, for example, Booysen (2001:47) does.

The texts on leadership often imply that the world in front of the text is the same as the implied world of the text as well as

4.See Caputo's interpretation of Heidegger's literal translation of the Latin dif-fere (Caputo 1982:151-152). the world behind the text, and because it is the same, the reader, through the author's 'world', can pass judgement on that which is supposed to be happening behind the text. In fear of oversimplifying, the author, the text and the reader generally presuppose that there is only one world (the real world) that is being talked about, and that the language (text) is the medium that communicates a truth about this one true world. On the basis of this truth, the leaders and leadership styles can be judged or criticised. What is forgotten is that there is not only one world, but differing worlds. What is forgotten is difference (Austrag).

What is necessary, is to think, and if one wishes to think what is forgotten, the following needs to be thought:

- There are different world-creations as humanity is weltbildend, or rather language is weltbildend.

- The wolf and the lamb: The differing world-creations have a sovereign that has the power (is authorised and legitimated) to judge according to 'universal standard'.

- The peculiar similarity between the sovereign and beast (Derrida 2011) even within the same world-creation.

- What if all this thinking is also weltbildend.

- Die Welt ist fort, ich muss dichtragen (The world is gone, I must carry you).

The rest of the article will more or less follow these five thought-paths in the light (Licht-ung) of reflecting on leadership.

\section{Humanity is weltbildend}

Heidegger in Die Grundbegriffe der Metaphyisik: Welt Endlichkeit - Einsamkeit argues that humans are weltbildend. For him, it is only humans who have the ability to create worlds, whilst animals are weltarm and stones (inanimate beings) are weltlos. ${ }^{5}$ This view of humanity and animals is, of course, also part of a particular Greek world-creation; in other words, it is part of a thinking that has been influenced by Greek thought, together with the thought-worlds of the three great monotheisms which have influenced and shaped Western thinking. These ideas are thus embedded or emplotted within the greater Western narrative (not that there is only one Western narrative). In this particular world, humans are interpreted as sovereigns who create their own world. They create their own world mostly unconsciously, through their being in language, where language is understood as the house of Being. Humans live in their socially constructed worlds. These world-creations of humanity are worlds in which a certain logos Waltet (Derrida 2011:42) - a logos that gathers and carries out a world (Austrag) into and out of the difference. Already in Being and Time (1996), Heidegger argued that logos, understood as speech, should be primarily understood as apophainesthai, as that which lets what is talked about be seen (phainesthai) as it is in itself (apo) (Heidegger 1996:280). It is this difference (Austrag) that is sovereign, that rules or reigns. Derrida refers

5." "The stone has no world," he says, der Stein istweltlos, "The animal is poor in world," das Tier is weltarm, "Man is world-configuring or world-forming," der Mensch is weltbildend" (Heidegger 1983:261ff.) (Derrida 2011:6). 
back to Heidegger's use of the term Walten when he says, that it is in the 'Austrag that it waltet' (Derrida 2011:256). Heidegger argues: 'Im Austrag waltet Lichtung des sich verhüllend Verschließenden, welches Walten das Aus-und Zueinander von Überkommnis und Ankunft vergibt' ${ }^{6}$ (Heidegger 1957:63). The Aus-und Zueinandervon Überkommnis und Ankunft is the way in which he in his later work describes the role of language (Heidegger 1971:206). Language, in and out of difference (Austrag), waltet, as things carry out or bear a world, just as world (carried out) grants to things their ontological place (Heidegger 1971:200).

Language, in and out of the Austrag, creates (poiesis) a world. These are the language worlds (narratives) into which events, like those mentioned above, are disclosingly appropriated. Each of these different world-creations are made up of the Geviert (fourfold: earth-sky-mortal-divinities) (Heidegger 1971:191ff.).

Thus, each world-poiesis contains some or other form of divinity. The divinities can be understood as the theoontological-political constitution of these worlds or their Logos; the divinities or the sovereign principle that is seen to be beyond the world, but that which not only gathers, but binds (religare) a world into a comprehensible whole. The divinities are the sovereign of that particular world. This has been interpreted as the religion or metaphysics of the particular world - religion understood as the ultimate meaning of that world (Berger 1967:32; Geertz 1995:90).

Thus, humans, who live in the house of being (language), which carries out their world, a world that includes some or other idea of sovereignty, find themselves under the power of that sovereign, which is part of the carried-out world of the speaking of their language. This sovereign Logos, in turn, also gives them the power or sovereign right (legitimate authority) to judge others in the light (Lichtung) of this Logos. It gives them the sovereign right to judge and declare who is beast and who not, as well as the sovereign power to declare what makes the beast a beast (backward or primitive).

There are different interpretations of leadership according to different narratives that, in turn, are embedded in different world-creations, gathered together by different logoi. There are the two dominant interpretations mentioned above, one that is embedded in the Western-world-creation and the other that is embedded in an African-world-creation. Bolden and Kirk (2009) seek to go beyond this simple dichotomy towards a more differentiated understanding of differing leadership styles. They identify four different categories of leadership theory, namely: essentialist, relational, critical and constructionist (Bolden \& Kirk 2009:71). Each of these four differing theories has its logos that binds the theory together into a comprehensible whole. For example, the essentialist theory is based on an objectivist or positivist world view. The relational is based on a more social-constructionist view of leadership, whereas the critical model focusses on the underlying powers at play in leadership, and the constructionist focusses on 'facilitation group processes'.

Each of these theories has this underlying logos (objectivism, social-constructivism, power, constructivism and deconstruction). The logos is the gathering or binding principle that gives birth to a particular world, by gathering the things of that world together and giving the things of that world their rightful place (ontology). It is because of this gathering logos that leadership styles can be understood and therefore also judged. If one is at home in a constructionist paradigm, then most leadership theories will be interpreted as being essentialist and therefore backward as they would be judged to be part of the modernistic paradigm. The essentialists would, in turn, argue that the constructivist argument is useless as it is too relativistic and will not solve any of the problems facing Africa.

Each theory (logos) co-creates a particular world and/or is part of a particular created world, and in that particular world, certain leadership styles are classified as ungovernable, chaotic and corrupt or the other culture is classified as individualistic, self-centred and goal-driven. To get involved in these battles between these theories, with their respective worlds, would only make sense if one still believes that one true and correct theory can be found, or that one has found it.

There are battles between these different leadership theories and worlds because there is power and there is interest- both interest in the sense of Sorge, as well as interest in the sense of capital gain. In a global context of different worlds, the question arises, who or what decides what leadership is? Who decides what is proper to leadership and whose interests does this interpretation of leadership serve?

From the above, it is clear that it is the Walten of the Logos that has the sovereign power to bestow the qualification 'good leadership' on a particular leadership style or theory. It is the Logos, which is the metaphysical principle (beyond the norm and law, yet instituting the norm), and therefore the sovereign, that decides what is proper and right. Thus, the question is: What is Logoswaltet in these differing worlds? Each of these differing worlds has a different logos, which determines (waltet) and in walting gathers and carries out a particular world.

\section{The sovereign and the beast or the wolf and the lamb}

Who or what is the sovereign to be able to declare what is good leadership?

The question in the context of sovereignty is: can the subaltern speak (Spivak 1988)? Can she or he be heard? In whose voice does she or he speak? If they speak in their own voice, this becomes a tendency to essentialise 'African' culture or the culture of the other (Nkomo 2011:377). The result is, 'In their 
efforts to cancel the negative images and/or invisibility of Africa, African management proponents often end up repeating the very errors they hope to erase' (Nkomo 2011:377). To argue that Ubuntu cannot only solve the African crisis (see Mangaliso 2001:32), but can also be a product to be exported from Africa to the rest of the world, that is, be a lesson the world can learn from Africa, does not question the basic managerial assumptions that are underlying the 'universal' theory to which Ubuntu would add value. In these essentialist theories, African culture is portrayed as a homogeneous whole, thereby not taking into consideration that Africa is a vast continent with numerous different cultures and traditions.

Instead of the binary between Africa and the West, one could move away from pure (Bhabha 1994) and essential interpretations of culture towards interpretations that appreciate the mutual effects of coloniser and colonised in what can be described as postcolonial thinking. The challenge is not to create a binary, but to create space for democracy-ofthought.

To create the necessary space for democracy-of-thought, the power games in the space need to be understood.

Who or what or wherefrom does the power come, 'the power that gives itself its own law, its force of law, its selfrepresentation, the sovereign and reappropriating gathering of self ...' (Derrida 2005:11)? Derrida argues that 'The sovereign, in the broadest sense of the terms, is he who has the right and the strength to be and be recognized as himself, the same, properly the same as himself' (Derrida 2009:66). The sovereign is he or she or that which has the power (Gewalt) to gather together a world, granting each thing (being) in that world its rightful (normative) place so that the world, as such, can come to self-consciousness.

\section{And again he argues:}

[T]he concept of sovereignty will always imply the possibility of this positionality, this thesis, this self-thesis, the autoposition of him who posits or posits himself as ipse, the (self-) same, oneself. (Derrida 2009:67)

Sovereign is understood as that which has the power to declare that which is proper to oneself or to someone. It declares what is proper to leadership. What is true of oneself, this ipseity includes the power, the force to proclaim that (Derrida 2005:17). Who is the sovereign, who is the one who is above the law, outside the law, who has the ability to dictate what is right, proper and lawful? And therefore, the ability to declare what is outside of what is right and proper to be labelled backward, wayward or rogue (Derrida 2005:19-20)?

The United Nations believes itself to have the duty to oversee the various sovereign nation states of the global village, and yet it does this on the basis of something that is beyond the particular laws and sovereignties of the various nation states. The United Nations was given the right, the sovereign right, to judge the laws and leadership styles of particular sovereign nation states on the basis of what it believes to be universal human rights and universal good governance. If a particular nation state contravenes or abuses human rights, the United Nations can impose, for example, economic sanctions. What logos gives (vergibt) (Heidegger 1957:63) to these universal rights, the right to be beyond the law (sovereign-law) of the various nation states, so as to be in a position to act as universal judge?

Derrida refers to Carl Schmitt, who argues that universal rights, which are believed to be above the particular nation states, is a form of neutralising or de-politicising (Entpolitisierung) of the state (Derrida 2009:71). Yet, Schmitt argues that this so-called de-politicising is in actual fact a hyperpoliticity (Derrida 2009:73). Universal human rights that pretend to de-politicise in actual fact hyper-politicise in the name of the Western state, declaring all those who do not uphold human rights, who do not subscribe to universal (Western) standards of governance, as being outside the law and therefore as beasts or backward and in need of Western intervention. In declaring the other as beast, the other may be treated as beast (outside the law). To accuse someone of being a beast (backward) means:

basically, of being virtually deprived, as is the beast, of all that is supposedly proper to man, beginning with language, but also reason, logos, as language and reason, the sense of death, technique, history, convention, culture, laughter, tears, etc., ... (Derrida 2009:167)

This is exactly what happens. Africa is seen to be backward and therefore they do not have a logos. They do not have the necessary theory and skills to solve their problems and are therefore in need of Western aid in the form of various leadership academies. If they are beasts they can be treated as such. But in treating the other as beast outside the law, oneself becomes beast, which the story of neocolonialism clearly reveals. There is no sovereign beyond the sovereign of the various worlds, be they nation states or not. The socalled sovereignty of universal human rights is just an universalisation (neocolonisation) of a particular Western nation state.

The fable about the fable concerning the sovereign, La Fontaine's the Wolf and the Lamb, reveals that the sovereign is always the beast. "The reason of the strongest is always the best' (Derrida 2009:7). The logos of the stronger is always the best, and is always what is right.

The sovereign, in always being right, is the wolf in the fable, yet the wolf is the beast.

\section{The beast is the sovereign}

This is perhaps what Derrida argues in The Beast $\mathcal{E}$ The Sovereign Vol I, that the beast and the sovereign are the same. In French, it is just the absence of one letter, between the beast and [et] the sovereign and the beast is [est] the sovereign (Derrida 2009:18). 
In this onto-zoo-anthropo-theologico-political copulation between sovereign and beast, one cannot distinguish the one from the other, as the one is the other.

It is within this context, this onto-zoo-anthropo-theologicopolitical context, that there is a sovereign and [et] a beast. Yet, it is also in this context that the beast becomes the sovereign and the sovereign becomes the beast: beast is [est] sovereign and sovereign is [est] beast. Derrida refers to Kant's distinction between warfare (Krieg) and conflict (Streit) (Derrida 2009:166-167). Conflict calls for a rational and institutional arbitration as opposed to war:

the accusation of bettise is a warlike response, an act of war that would achieve the rational status of conflict only on the hypothesis that someone, a third party or an institution, could determine both the meaning of the word betise and the justness, justice, justification or not of the accusation. (Derrida 2009:167)

Who can determine that meaning? There is no transcendent rule, no transcendent inalienable human rights or universal theory of leadership that can arbitrate between these different worlds. These different worlds can be thought of as different ecologies of thought (worlds of a particular logos) or, as Laruelle (2013b) argues, as ethologos, which could be developed into something like etho-spheres, or as Sloterdijk (2011) might argue, bubbles. Each sphere has its own ontology and ethics, based on its own conscious or subconscious metaphysics, the logos (ethologos) that waltet over that particular world (ethosphere). Maybe it would be useful to introduce a term of lived metaphysics or lived logos, that is the logos that waltet in a particular world.

The metaphysics or the sovereign divinities of these spheres (worlds) can be compared to Aristotle's Prime Mover. There is no escaping this metaphysics to a place from where one could compare and judge these different world-creations carried out by differing logoi. There is nothing beyond metaphysics, only a closure, or enclosure within metaphysics (see Derrida 1981:13).

\section{What if this thinking is also weltbildend?}

The infamous statement by Derrida that there is nothing beyond the text (Derrida 1997:158) might help in this regard. There is nothing beyond the text, in other words, there are no universal leadership theories, but nor are there particular cultural-religious pre-colonial essentialist leadership theories either, as both are part of a particular world-creation.

Can there be no absolute sovereign? Heidegger, according to Derrida, argues for the Walten der Differenz (Derrida 2011:207). Is this Walten der Differenz a new absolute sovereign, beyond the sovereigns of the various worlds?

Is the Walten der Differenz not just another logos that gathers together a world by carrying it out? Or is this Walten der Differenz something different, something sovereign beyond the sovereignty of the onto-theological sovereignty of the different worlds?

Walten der Differenz is different and cannot be equated with the various sovereign logoi. 'Walten would be too sovereign still to be sovereign, in a sense, within the limits of the theologicopolitical. And the excess of sovereignty would nullify the meaning of sovereignty' (Derrida 2011:279). It is different to the onto-theological God as causa sui, as one cannot dance and sing and make sacrifices to this onto-theological God (Heidegger 1957:70). Maybe the God of Abraham and Jacob can offer an alternative sovereignty that is not sovereign in the metaphysical sense. If we take a step back (Heidegger 1957: 71-72), a step back that brings us back from forgetting of Differenz, if one takes that step back and no longer forgets the Walten der Differenz, but remembers it, what then? Then, the world as such is gone. Die Welt is fort, ich muss dichtragen.

\section{Die Welt ist fort, ich muss dich tragen - Christian servant leadership}

Die Welt ist fort, ich muss dich tragen, ich muss dich Austragen, ich muss dich ertragen! The world is gone and I must take responsibility for you and for it. I must carry it, take the burden of it upon myself, take the responsibility for you and for it upon myself (see Derrida 2011:268). The world is gone, the world must be carried out (Austragen). This opens the way for an ethos of responsibility for the other, whoever or whatever the other is.

The God, the sovereign onto-theological God has been crucified and we are left with a God to whom we can dance, sing and above all pray. The God of faith revealed to the faith of the fathers, Abraham, Isaac and Jacob. The world-creating logos, the world forming logos became flesh, the New Testament tells in the Prologue to the Gospel of John. The logos entered into the world-creation, entered history, and in the history was crucified, accused of blaspheming the ontotheological gods. The world-creating logos was crucified and thus the world is gone with the crucified logos, die Welt ist fort. We are all like stones, weltlosoderweltverlorene - unchained from the world or from the sun, the logos-light (-Licht) which creates the world (Lichtung) is dead. The world has been unchained from its sun (Nietzsche 1974:181-182). Unchained from the sovereign logos that has the power to Walt over the world. That leaves one as a child, the last Verwandelung, without a world, besides the world that one has co-created: a temporal and spatial world, as it is a world-creation within a very specific Zeit-Spiel-Raum (see Caputo 1993:30). Nietzsche's last Verwandelung into a child is a child who needs to be carried, both carried to be born and carried until it is grownup enough to stand on its own feet: ich muss dichtragen.

Die Welt ist fort, ich muss dich tragen. Who is authorised to say these words and to whom are they said? Who carries

7.'Drei Verwandlungen nenne ich euch des Geistes: wie der Geist zum Kamele wird, und zum Löwen das Kamel, und zum Kinde zuletzt der Löwe' (Nietzsche 2000). 
whom in this weltverlorene, weltlose Welt of the child without a sovereign Father? One could carry another, carrying each other's worlds by respecting each other's worlds. All the different worlds would stand next to and thus equal to each other, yet without a universal Logos by which to compare or even judge or evaluate the different worlds. Such a situation would be absolute relativism and the result would be a total breakdown of communication in the global village. Are all these worlds equal? They are equally created, and as created equally, haunted by différance. Maybe the ethos that I am proposing is not an ethic of Streit and Krieg on the basis of some or other arbitrating principle, but rather an ethos of listening to the haunting cries of those who are weltarm or even weltlos in these various worlds. The stones who are weltarm and weltlos will cry out, as Luke 19 says, to prepare the way for a king, a sovereign who is different, to whom one can sing, sacrifice and pray.

It is an ethos of listening to those who carry the burden of their particular worlds. They, who are weltarm or even weltlos carry the burden of the weltbildenden sovereigns or leaders. Listen to their stories, not because their stories are truer or better, but because only they can tell us the weight, the weight in gold, of the world they carry.

It is not the Western world with its sovereignty and leadership theories that can judge the leaders in Africa, nor the religious or cultural world of Africa with its sovereignty of African nationalism, which is better, as both are world-creations. Often these world-creations are embedded in different global-political or geo-political world-creations. All these worlds are equally weltbildend and therefore weltlos as such. From no point or point of view would one have a better view, but maybe from the view of those who suffer the weight of these worlds. An ethos is offered, of listening to the cries of the destroyed lives that haunt these world-creations. These cries of those who are truly weltlos because they are either dead or treated like stones (objects) offer a perspective (hauntology) by which to weigh the weight of these worlds. Thereby offering these crying-out-stones (Luke 19:37-40) and restless souls, the living dead, a place in a world where they can rest: be at home and no longer weltlos, as they pray to the sovereign of the world still to come. Not a Western world nor an African traditional world, but a world to come, a world of the child, beast and stone: where the wolf shall dwell with the lamb, and the leopard shall lie down with the kid; and the calf and the young lion and the fatling together; and a little child shall lead (carry) them (Isaiah 11:6).

\section{Acknowledgements Competing interests}

The author declares that he has no financial or personal relationships that may have inappropriately influenced him in writing this article.

\section{References}

African leadership academy, n.d., home page, viewed n.d., from http://www. africanleadershipacademy.org/

Andreasson, S., 2005, 'Orientalism and African development studies: The reductive repetition Motif in theories of African underdevelopment', Third World Quarterly 26(6), 971-986.

Appiah, K.A., 1992, In My Father's House: Africa in the philosophy of culture, Oxford University Press, New York.

Aspen institute, n.d., South African Fellows Fight on in the Name of Mandela, viewed n.d., from http://www.aspeninstitute.org/leadership-programs/africa-leadershipinitiative/south-africa

Ayittey, G.B.N., 1998, Africa in Chaos, St. Martin's Press, New York.

Berger, P., 1967, The sacred canopy: Elements of a sociological theory of religion, Anchor Books, New York.

Bhabha, H.K., 1994, The location of culture, Routledge, New York.

Bob-Milliar, G., 2005, Re: The failure of African leadership, cause of Africa's problems, modern Ghana, viewed 24 June 2014, from http://www.modernghana.com/ news/116901/1/re-the-failure-of-african-leadership-cause-of-afri.html

Bolden, R., \& Kirk, P., 2009, 'African leadership: Surfacing new understandings through leadership development', International Journal of Cross Cultural Management 9 , leadership development', International Journal of Cross

Booysen, L., 2001, 'The duality in South African leadership: Afrocentric or Eurocentric', South African Journal of Labour Relations, Spring/Summer 2001, 36-64.

Caputo, J.D., 1982, Heidegger and Aquinas: An essay on overcoming metaphysics, Fordham University Press, New York.

Caputo, J.D., 1993, Demythologizing Heidegger, Indiana University Press, Indianapolis,

Césaire, A., 1972, Discourse on Colonialism (1955), transl. J. Pinkham, Monthly Review Press, New York.

Coote, B., 1995, 'The trade trap', in S. Hernandez (ed.), Introductory Reader on NorthSouth Issues for the Autumn University "Play Fair Europe! Aachen," 25th of September - 8th of October 1995, pp. 75-104, Play Fair Europe, Aachen.

DeMaria, B., 2008, 'Neo-colonialism through measurement: A critique of the corruption perception index', Critical Perspectives on International Business 4(2/3), 184-202. https://doi.org/10.1108/17422040810870079

Derrida, J., 1981, Positions, transl. A. Bass, Athlone Press, London.

Derrida, J., 1997, Of grammatology, transl. G.C. Spivak, John Hopkins University Press, London.

Derrida, J., 2005, Rogues: Two essays on reason, transl. P.-A. Brault \& M. Naas, Stanford University Press, Stanford, CA.

Derrida, J., 2009, The beast \& the Sovereign, vol. 1, transl. G. Bennington, University of Chicago Press, Chicago, IL.

Derrida, J., 2011, The Beast \& the Sovereign, vol. II, transl. G. Bennington, University of Chicago Press, Chicago, IL.

Fanon, F., 1967, 'First truths on the colonial problem', in Toward the African revolution transl. H. Chevalier, pp. 120-126, Harmondsworth, Penguin.

Fanon, F., 1990, The wretched of the earth, 3rd translation, transl. C. Farrington, Harmondsworth, Penguin.

Forbes, n.d., Leadership, viewed n.d., from http://www.forbes.com/leadership/

Geertz, C., 1993, 'Religion as a cultural system', in The interpretation of cultures: Selected essays by Clifford Geertz, pp. 87-125, Fontana Press, London.

Harris, P.R., Moran, R.T. \& Moran, S.V., 2004, Managing cultural differences: Global leadership strategies for the twenty-first century, 6th edn., Elsevier ButterworthHeinemann, Burlington, MA.

Heidegger, M., 1957, Identität und differenz, Verlag Günther Neske, Pfullingen.

Heidegger, M., 1971, Poetry, language and thought, transl. A. Hofstadter, Harper \& Row, New York.

Heidegger, M., 1983, Die Grundbegriffe der Metaphyisik: Welt - Endlichkeit Einsamkeit, Freiburger Vorlesung Wintersemester 1999/30, Herausgegeben von Friedrich-Wilhelm von HerrmannVitorio Klosterman, Frankfurt am Main

Heidegger, M., 1996, Being and time: A translation of Sein und Zeit, transl. J. Stambaugh, State University of New York Press, New York.

Hofstadter, A., 1971, 'Introduction', in M. Heidegger (ed.), Poetry. Language, thought, pp. ix-xxii, Harper \& Row, New York.

Hofstede, G., 1980, Culture's consequences: International differences in work-related values, Sage, Beverly Hills, CA.

Hofstede, G., 1993, 'Cultural constraints in management theories', Academy of Management Executive 7(1), 81-94. https://doi.org/10.5465/AME.1993.940914 2061

House, R.J., 1993, A proposal to conduct a multination study of leadership and organizational practices, Unpublished manuscript, PA.

House, R.J., 1996, Prospectus: An update on the GLOBE study, Unpublished manuscript, PA

House, R.J., Hanges, P.J., Dickson, M.W., Ruiz-Quintanilla, S.A. \& Globe CCl's, 1998 Culture and leadership scales, Unpublished manuscript.

House, R.J., Wright, N.S. \&Aditya, R.N., 1997, 'Cross-cultural research on organizational leadership. A critical analysis and a proposed theory', in P.C. Earley \& M. Erez leadership. A critical analysis and a proposed theory', in P.C. Earley \& M. Erez
(eds.), New perspectives on international industry/organizational psychology, pp. (eds.), New perspectives on international ind 
Khoza, R., 1994, 'The need for an Afrocentric management approach - A South African based management approach', in P. Christie, R. Lessem \& L. Mbigi (eds.), African
management. Philosophies, concepts and applications, pp. 117-124, Sigma, manage
Pretoria.

Laruelle, F., 2013a, Principles of non-philosophy, transl. N. Rubczak \& A.-P. Smith, Bloomsbury, London, Kindle edition, viewed n.d., from http://www.bloomsbury. com

Laruelle, F., 2013b, Principles of non-philosophy, Kindle Location 26, Bloomsbury Publishing, Kindle Edition, Lincoln.

Mangaliso, M.P., 2001, 'Building competitive advantage from Ubuntu: Management lessons from South Africa', Academy of Management Executive 15(3), 23-32. https://doi.org/10.5465/AME.2001.5229453

Martin, W.G., 2008, 'Africa's futures: From North-South to East-South?', Third World Quarterly 29(2), 339-356. https://doi.org/10.1080/01436590701822928

Matsengarwodzi, D., 2013, Leadership Crisis in Africa: Words have turned into bullets that maim the innocent, Nehanda Radio, viewed 25 June 2014, from http:// nehandaradio.com/2013/09/30/words-have-turned-into-bullets-that-maim-theinnocent/

Mbembe, A., 1992, 'Provisional notes on the Postcolony', Africa 62(1), 3-37. https:// doi.org/10.2307/1160062

Mbembe, A., 2001, On the Postcolony, University of California Press, Berkeley, CA.

Mbembe, A., 2002a, 'African modes of self-writing', transl. S. Rendall, Public Culture 14(1), 239-273. 'https://doi.org/10.1215/08992363-14-1-239

Mbembe, A., 2002b, 'On the power of the false', transl. J. Inggs, Public Culture 14(3), 629-641. https://doi.org/10.1215/08992363-14-3-629

Meylahn, J.-A., 2017, 'Practicing Ubuntu beyond, against or with Christian texts', in J. Dreyer, Y. Dreyer, E. Foley, M. Nel (eds.), Practicing Ubuntu: Practical theological perspectives on injustice, personhood and human dignity, pp. 123-134, Lit Verlag, perspectives on injustice, personh

Mudimbe, V.Y., 1988, The invention of Africa: Gnosis, philosophy, and the order of knowledge, Indiana University Press, Bloomington, IN.

Nietzsche, F., 1974, The Gay science, transl. ed. W. Kaufmann, Vintage, New York.

Nietzsche, F.W., 2000, Also sprach Zarathustra, e-book, Projekt Gutenberg, viewed n.d., from http://www.gutenberg2000.de/nietzsche/zara.also.htm
Nkomo, S., 2011, 'A Post-colonial and anti-colonial reading of "African" leadership and management in organization studies: Tensions, contradictions and possibilities', management in organization studies: Tensions, contradictions and possibi
Organization 18, 365-386. https://doi.org/10.1177/1350508411398731

Obiakor, F.E., 2004, 'Building Patriotic African Leadership through African-centred education', Journal of Black Studies 34, 402-420. https://doi.org/10.1177/ 0021934703258757

Ricoeur, P., 1984, Time and narrative, vol. 1, transl. K. McLaughlin \& D. Pellauer, University of Chicago Press, Chicago, IL.

Sloterdijk, P., 2011, Bubbles: Spheres 1, transl. W. Hoban, Semiotext(e), Los Angeles, CA.

Said, E., 1979, Orientalism, Vintage, New York.

Said, E., 1993, Culture and imperialism, Chatto and Windus, London.

Senghor, L.S., 1964, On African socialism, transl. M. Cook, Pall Mall, London.

Senghor, L.S., 1994, 'Negritude: A humanism of the twentieth century', in P. Williams \& L. Chrisman (eds.), Colonial discourse and Postcolonial theory, pp. 27-35, Columbia University Press, New York.

Spivak, G.C., 1988, 'Can the Subaltern speak?', in C. Nelson \& L. Grossberg (eds.), Marxism and the interpretation of culture, pp. 271-313, Macmillan, London.

The Aspen Institute, n.d., African Leadership Initiative, viewed 04 July 2014, from http://www.aspeninstitute.org/leadership-programs/africa-leadership-initiative/ south-africa

The Economist, 2000, 'Africa: The hopeless continent', The Economist, May 11, viewed 04 July 2014, from http://www.economist.com/node/21519234

The Herold, 2013, 'Tsvangirai: puppet on a string?', The Herold, August 09, viewed 04 July 2014, from http://www.herald.co.zw/tsvangirai-puppet-on-a-string/

The Leadership Magazine, n.d., Leadership, viewed 04 July 2014, from www. leadershiponline.co.za

The Socialist Party of Great Britain, 2000, Africa: The Lost Continent?, 11 May 2000, viewed 04 July 2014, from http://www.worldsocialism.org/spgb/education/ depth-articles/politics-and-conflict/africa-lost-continent

Triandis, H.C., 1995, 'A theoretical framework for the study of diversity', in M.M. Chemers, S. Oskamp \& M.A. Costanzo (eds.), Diversity in organizations: New perspectives for a changing workplace, pp. 11-36, Sage, London. 